\title{
First Record of Rhynchotermes nasutissimus (Silvestri) (Isoptera: Syntermitinae) Associated with Rat Carrion in Brasília, Brazil
}

\author{
Anna Carolina Prestes ${ }^{\bowtie}$, Karla Pessôa Tepedino ${ }^{1}$, Cecília Kosmann² \& José Roberto Pujol-Luz
}

1. Universidade de Brasília, e-mail: annacarolina.prestes@gmail.com (Autor para correspondência ${ }^{\bowtie}$ ), karlaptp@gmail.com, jrpujol@unb.br. 2. Universidade Estadual Paulista “Júlio de Mesquita Filho", Faculdade de Ciências e Letras de Assis , e-mail: ceciliakosmann@gmail.com.

\section{EntomoBrasilis 7 (1): 58-61 (2014)}

Abstract. Rhynchotermes nasutissimus (Silvestri) is a leaf litter species with Neotropical distribution. We found for the first time this species associated with rat carrion in an urban area of Brasília, Distrito Federal, Brazil. Ten soldiers and 36 workers were spread in the cavities and between internal leathers of the carrion's dry remains of the animal that have been exposed during a week in the soil, in March 2012, at end of the wet season. We believe that this uncommon behavior may reflect a nutritional need.

Keywords: Cerrado; Necrophagous insects; Neotropical; Termites.

\section{Primeiro Registro de Rhynchotermes nasutissimus (Silvestri) (Isoptera: Syntermitinae) Associado à Carcaça de Rato em Brasília, Brasil}

Resumo. Rhynchotermes nasutissimus (Silvestri) é uma espécie que se alimenta de folhas de serrapilheira e que possui distribuição Neotropical. Encontrou-se pela primeira vez esta espécie associada com carcaça de rato, em uma área urbana de Brasília, Distrito Federal, Brasil. Os dez soldados e 36 operários se encontravam dispersos entre as vértebras e restos secos do animal que foi exposto durante uma semana no solo em março de 2012, final da estação chuvosa. Acredita-se que este comportamento raro seja resultado de alguma deficiência nutricional.

Palavras-Chave: Cupins, Cerrado; Insetos necrófagos, Neotropical.

$\sqrt{ }$ lermites are eusocial insects distributed on tropical and subtropical regions (EGgleton et al. 1994). The Order Isoptera comprises approximately 2,900 species, of which 562 are present in the Neotropical region (KRISHNA et al. 2013). They are considered as primary consumers and decomposers, feeding on a wide range of plant material in different stages of decomposition as well as in soil rich in organic matter (e.g., wood, litter, roots, humus, grass, herbaceous plants, nests built by others termites, lichen, and fungi) (LEE \& WOOD 1971; WOOD 1978).

However, some studies have reported the presence of termites in animal carcasses (Table 1). Species of the families Termitidae, Rhinotermitidae, and Mastotermitidae have already been recorded in recent bones, fossils ( $>1,000$ years), hooves, horns, skins, cartilages, and ligaments of mammals (including humans), reptiles and birds. FreYMANN et al. (2007) assumed that Odontotermes sp. is facultative kerathophagous due to its frequency of foraging in ungulates hooves. VILLET (2011) listed Isoptera as one of the 'necrophagous African carrion insects' based in the survey of CoE (1978) that mentioned Odontotermes zambesiensis (Sjostedt) feeding on elephants's ligaments and cartilages. Nevertheless, the latter author classified the termites as omnivorous animals or 'opportunistic scavengers', highlighting that this term can be quite broad and malleable.

The action of termites can be a serious problem to archeological material, since it commits the preservation of it and can induce to erroneous interpretations (WYLIE et al. 1987). Due to this scenario, the reports of termites associated with fossils are more common that the ones associated with carcasses.
Thorne \& Kimsey (1983) described a group of Nasutitermes sp. foraging on bones and skin of a three meters boa snake on Barro Colorado Island, Panama. Latter, they founded an active foraging group of Nasutitermes nigriceps (Haldeman) under a three-toed sloth carcass and a decomposing turtle shell covered by a network of Nasutitermes sp. galleries over cavities around spinal column. Finally, they carried out an observational experiment with an agouti carcass inside a cage and $N$. nigriceps was observed again. The termites constructed galleries from the ground until one of the legs of the agouti, when there was no more musculature or internal organs. With the end of the dry season, the termites left the carcass, which may reflect a seasonal and nutritional needs of these insects (the authors did not identify the species of boa snake, turtle, three-toed sloth, and agouti at the specific level).

Another study was conducted in the Neotropical region with rat carrion in northern Venezuela (VELÁsQuez 2008). Carcasses were exposed to colonization by arthropods in areas of savannah and cloud forest. Beside the species of forensic importance, Termitidae were observed only in the savanna.

We found Rhynchotermes nasutissimus (Silvestri) associated with rat carrion (Figure 1) exposed in an urban area near from the Universidade de Brasília, Distrito Federal, Brazil. Soldiers $(n=10)$ and workers $(n=36)$ were spread in the cavities of the rat, as wells as in the pelvis and between internal leathers of the carrion's dry remains.

Funding Agencies: FAP-DF, CNPq and CAPES 
Table 1. Species of termites (Insecta: Isoptera) reported associated with carcasses.

\begin{tabular}{|c|c|c|c|c|}
\hline Species & Subfamily & Type of carcass & Local & Reference \\
\hline- & - & Human bones & Ancient Nubia, Egypt & {$[1]$} \\
\hline Coptotermes formosanus Shiraki & Rhinotermitidae & Human bones & China & {$[2]$} \\
\hline- & - & Human bones & Queensland, Australia & {$[3]$} \\
\hline - & - & $\begin{array}{l}\text { Recent bones and mammal's } \\
\text { fossils }\end{array}$ & $\begin{array}{l}\text { Amboseli National Park, } \\
\text { Kenia }\end{array}$ & {$[4]$} \\
\hline $\begin{array}{c}\text { Odontotermes zambesiensis } \\
\text { (Sjöstedt) }\end{array}$ & $\begin{array}{c}\text { Termitidae: } \\
\text { Macrotermitinae }\end{array}$ & $\begin{array}{c}\text { Elephants's cartilages and } \\
\text { ligaments }\end{array}$ & Tsavo, Kenia & {$[5]$} \\
\hline $\begin{array}{l}\text { Nautitermes nigriceps } \\
\text { (Haldeman) }\end{array}$ & $\begin{array}{c}\text { Termitidae: } \\
\text { Nasutitermitinae }\end{array}$ & $\begin{array}{l}\text { Insects larvaes; reptiles and } \\
\text { mammals's bones, skins and } \\
\text { marrows }\end{array}$ & Barro Colorado, Panama & {$[6]$} \\
\hline $\begin{array}{c}\text { Coptotermes acinaciformis } \\
\text { (Froggatt) }\end{array}$ & Rhinotermitidae & $\begin{array}{l}\text { Recent bones and mammal's } \\
\text { fossils }\end{array}$ & Laboratory experiment & {$[7]$} \\
\hline $\begin{array}{c}\text { Nasutitermes carnarvonensis } \\
\text { (Hill) }\end{array}$ & $\begin{array}{c}\text { Termitidae: } \\
\text { Nasutitermitinae }\end{array}$ & Human bones & Carnarvon Region, Australia & {$[8]$} \\
\hline $\begin{array}{c}\text { Pseudacanthotermes militaris } \\
\text { (Hagen) }\end{array}$ & Mastotermitidae & $\begin{array}{l}\text { Recent bones and mammal's } \\
\text { fossils }\end{array}$ & Carnarvon Region, Australia & {$[8]$} \\
\hline $\begin{array}{l}\text { Mastotermes darwiniensis } \\
\text { (Froggatt) }\end{array}$ & $\begin{array}{c}\text { Termitidae: } \\
\text { Macrotermitinae }\end{array}$ & Elephants bones & $\begin{array}{l}\text { Hwange National Park, } \\
\text { Zimbabwe }\end{array}$ & [9] \\
\hline- & - & Mammals's recent bones & Zaire, Angola & {$[10]$} \\
\hline * & - & Human fossil & Laetoli, Tanzania & {$[11]$} \\
\hline Odontotermes sp. & $\begin{array}{c}\text { Termitidae: } \\
\text { Macrotermitinae }\end{array}$ & $\begin{array}{c}\text { Grant's gazelle's carcass and } \\
\text { hooves }\end{array}$ & Serengueti, Tanzania & {$[12]$} \\
\hline- & Termitidae & Rat carrion & Caracas, Venezuela & {$[13]$} \\
\hline Reticulitermes sp. & Rhinotermitidae & Pig carrion & Uyo, Nigéria & {$[14]$} \\
\hline- & - & Human bones & Huaca de Luna, Peru & {$[15]$} \\
\hline $\begin{array}{c}\text { Trinervitermes trinervoides } \\
\text { (Sjöstedt) }\end{array}$ & $\begin{array}{c}\text { Termitidae: } \\
\text { Nasutitermitinae }\end{array}$ & Bones (birds and mammals) & $\begin{array}{c}\text { Sterkfontein Valley, South } \\
\text { Africa }\end{array}$ & {$[16]$} \\
\hline
\end{tabular}

$(-)$ not specified in the article; $(*)$ Termites are suggested as possible producers of marks and modifications on humans fossil from Plio-Pleistocene. References: [1] Derry 1911; [2] Light 1929; [3] Wood 1976; [4] BeHrensmeyer 1978; [5] Coe 1978; [6] Thorne \& Kimsey 1983; [7] Watson \& AbBey 1986; [8] Wylie et al. 1987; [9] Haynes 1991; [10] TAPPEN 1994; [11] Kaiser 2000; [12] Freymann et al. 2007; [13] VelásqueZ 2008; [14] EkANEm \& Dike 2010; [15] HuCHET et al. 2011; [16] BACKWELL et al. 2012.
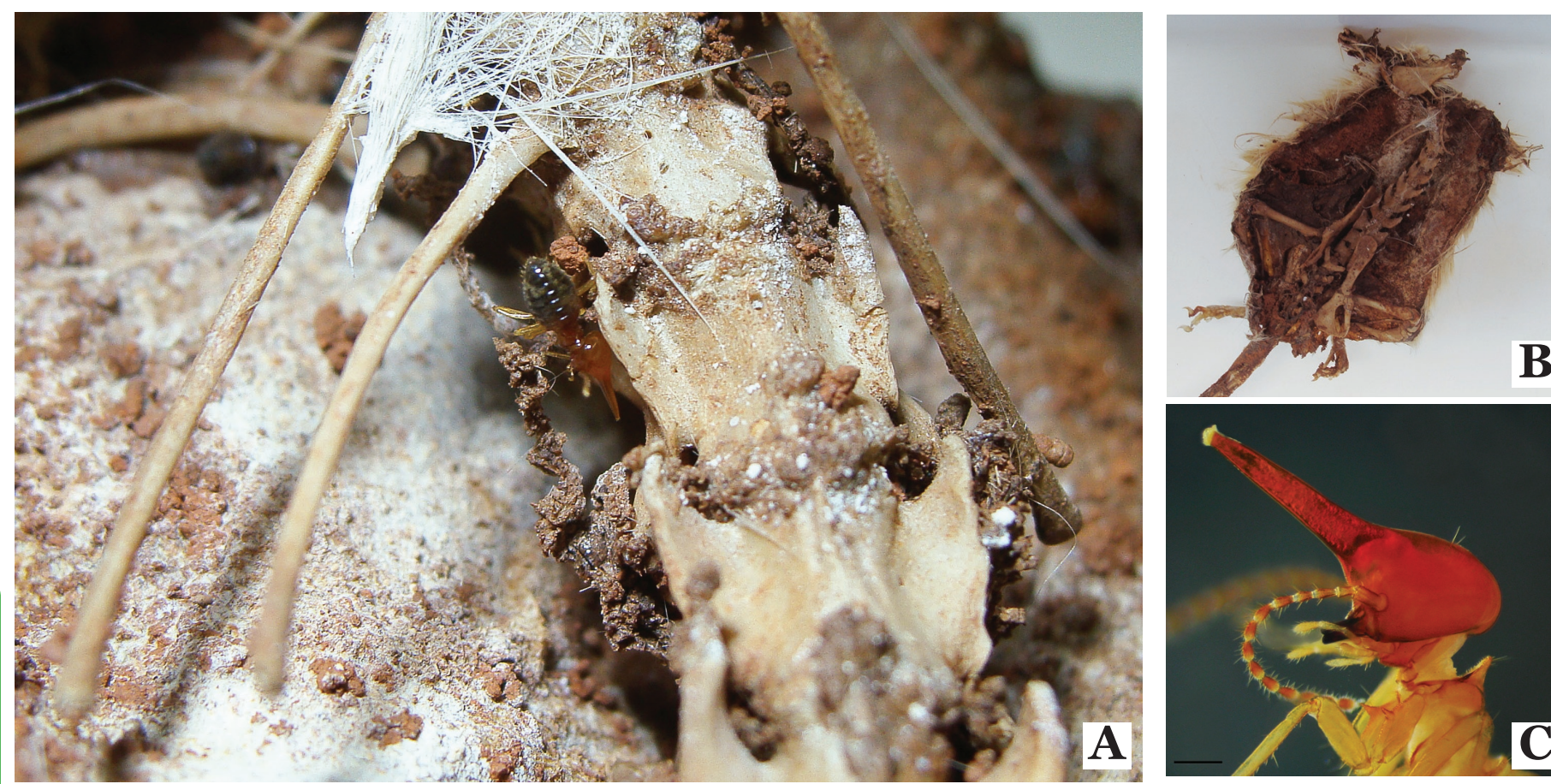

Figure 1. Rhynchotermes nasutissimus (Silvestri) associated with rat carrion in Brasília, Distrito Federal, Brazil. A) Soldier of R. nasutissimus between the vertebrae of the rat; B) Ventral view of the dry rat carrion; C) Closer view of a soldier of $R$. nasutissimus (scale o.5 mm) (Figure C: photo from Tiago Carrijo). 
R. nasutissimus is distributed through Argentina, Bolivia, Brazil, Paraguay, and Peru (Constantino 2013), and in it has been collected in different phytophysiognomies of Cerrado (CANCELLO 1997). The information about the biology of this genus is scarce, but they are generally considered as leaf litter feeder species (Donovan et al. 2001) that forage on the ground surface and spread through subterranean galleries in forests and savannas when disturbed (Mathews 1977). According to Mathews (1977), this species has never been found in mounds of other species. However, the labels of specimens deposited in the entomological collection of the Museu de Zoologia of the Universidade de São Paulo contain some information about the collection site: "founded on the ground, underground, on palm leaves, on grass, under cattle dung, under log, in Cornitermes sp. nest, along with other species". The pattern of the workers' mandibles of is described as "long, broad sharpened margins appropriate for vegetal fibers cutting" (CANCELLO 1997), and there is no record about its association with carrion.

In specific and unusual circumstances, coprophagy, necrophagy, cannibalism, and oophagy can be ways of conserving and/or recycling nitrogen, an essential constituent for the synthesis of protein and growth of the colony (WOOD 1978). These behaviors (i.e., selective foraging) and the nitrogen fixation are strategies to survive in a cellulose-based diet, generally low in organic nitrogen (Prestwich et al. 1980; SLAYTOR \& Chappel 1994).

As previously said, the attraction to carcass may reflect a seasonal nutrition needs for the production and dispersion of alates after the dry season (Thorne \& KIMSEY 1983). Here the termites were associated with carrion in the final stage of the wet season, when the swarming flights usually have already finished in the Cerrado (Brandão 1996, Prestes 2012). In the wet season (November to April), the average rainfall is $184.7 \mathrm{~mm}$ and the relative humidity, $75.7 \%$. The average minimum temperature in this season is $17^{\circ} \mathrm{C}$ and the maximum, $26^{\circ} \mathrm{C}$ (EITEN 1972; Pinheiro et al. 2002). More investigations about the frequency of this species on carrion are necessary for a better understanding of its range of foraging and feeding habits.

\section{ACKNOWLEDGMENTS}

The authors thank Joice Constantini and M.Sc. Tiago Carrijo from Laboratório de Isoptera of Museu de Zoologia of the Universidade de São Paulo for the identification and photos of the termites, respectively. We are indebted to the collaboration and kindness of Dr. Barbara Thorne from the University of Maryland in sharing information about her work. We are also grateful to CNPq (JRPL, CK, TPT), CAPES (CK) and FAPDF (JRPL, CK) for the grants.

\section{REFERENCES}

Backwell, L.R., A.H. Parkinson, E.M. Roberts, F. d'Erricoc \& J-B. Huchet, 2012. Criteria for identifying bone modification by termites in the fossil record. Palaeogeography, Palaeoclimatology, Palaeoecology, 337-338: 72-87.

Behrensmeyer, A.K., 1978. Taphonomic and ecologicinformations from bone weathering. Paleobiology, 4/2: 150-162.

Brandão, D., 1996. Estudo sobre o padrão de revoadas de uma comunidade de térmites no Parque Nacional das Emas, Goiás. Tese (Doutorado em Ecologia) - Universidade de Campinas.

Cancello, E.M., 1997. Rhynchotermes guarany, new species and Rhynchotermes piauy, new species (Isoptera, Termitidae, Nasutitermitinae) from Brazil. Papéis Avulsos de Zoologia da Universidade de São Paulo, 40: 147-159.

Coe, M., 1978. The decomposition of elephant carcasses in the Tsavo (East) National Park, Kenya. Journal of Arid Environments, 1: 71-86.

Constantino, R. Online Database. Available in: $<$ http://www.termitologia.unb.br $>$ [Acessed on 03.05.2013].

Derry, D.E., 1911. Damage done to skulls and bones by termites.
Nature, 86: 245-246.

Donovan, S.E., P. Eggleton \& D.E. Bignell, 2001. Gut content analysis and a new feeding group classification of termites. Ecological Entomology, 26: 356-366.

Eggleton, P., P.H. Williams \& K. Gaston, 1994. Explaining global termite diversity: productivity or history. Biodiversity and Conservation, 3: 318-330.

Eiten, G.,1972. The cerrado vegetation of Brazil. The Botanical Review, 38: 201-341.

Ekanem, M.S., \& M.C. Dike, 2010. Arthropod succession on pig carcasses in Southeastern Nigeria. Papéis Avulsos de Zoologia da Universidade de São Paulo, 50: 562-570.

Freymann, B.P., S.N. Visser, E.P. Mayemba \& H. Olff, 2007. Termites of the genus Odontotermes are optionally keratophagous. Ecotropica, 13: 143-147.

Haynes, G., 1991. Mammoths, mastodonts and elephants. Biology, behavior and the fossil record. Cambridge University Press, Cambridge, 413p.

Huchet, J.B., D. Deverly, B. Gutierrez \& C. Chauchat, 2011. Taphonomic evidence of a human skeleton gnawed by termites in a Moche-Civilisation grave at Huaca de la Luna, Peru. International Journal of Osteoarchaeology, 21: 92102.

Kaiser, T.M., 2000. Proposed fossil insect modification to fossil mammalian bone from Plio- Pleistocene hominid-bearing deposits of Laetoli (Northern Tanzania). Entomological Society of America, 93: 693-700.

Krishna, K., D.A. Grimaldi, V. Krishna, \& M.S. Engel, 2013. Treatise on the Isoptera of the world. Bulletin of the American Museum of Natural History, 1: 1-2704.

Lee, K.E. \& T.G. Wood, 1971. Termites and soils. London, Academic Press of London, 251p.

Light, S.F., 1929. Present status of our knowledge of the termites of China. Lignan Science Journal, 7: 581-600.

Mathews, A.G.A., 1977. Studies on termites from the Mato Grosso State, Brazil. Rio de Janeiro, Academia Brasileira de Ciências, 267p.

Pinheiro, F., I.R. Diniz, D. Coelho \& M.P.S. Bandeira, 2002. Seasonal pattern of insect abundance in the Brazilian cerrado. Austral Ecology, 27: 132-136

Prestes, A.C., 2012. Padrão de revoadas de cupins (Isoptera) em duas áreas de cerrado no Brasil Central. Dissertação (Mestrado em Biologia Animal) - Universidade de Brasília, $48 \mathrm{p}$.

Prestwich, G.D., B.D. Bentley \& E.J. Carpenter, 1980. Nitrogen sources for neotropical nasute termites: fixation and selective foraging. Oecologia, 46: 397-401.

Slaytor, M. \& D.J. Chappell, 1994. Nitrogen metabolism in termites. Comparative Biochemistry and Physiology, 107: $1-10$.

Tappen, M., 1994. Bone weathering in the tropical rain forest. Journal of Archaeological Science, 21: 667-673.

Thorne, B.L. \& R.B. Kimsey, 1983. Attraction of neotropical Nasutitermes termites to carrion. Biotropica, 15: 295-296.

Velásquez, Y., 2008. A checklist of arthropods associated with rat carrion in a montane locality of northern Venezuela. Forensic Science International, 174: 67-69.

Villet, M.H., 2011. African carrion ecosystems and their insect communities in relation to forensic entomology. Pest Technology, 5: 1-15

Watson, J.A.L. \& H.M. Abbey, 1986. The effects of termites (Isoptera) on bone: some archeological implications. Sociobiology, 11: 245-254.

Wood, T.G., 1978. Food and feeding habits of termites, p. 55-80. In: Brian, M.V. (Ed.). Production ecology of ants and termites. Cambridge, Cambridge University Press, 409p.

Wood, W.B., 1976. The skeletal material from the Brooloo Range and Rocky Hole Creek burial sites. Archaeology and Physical Anthropology in Oceania, 11: 175-185.

Wylie, F.R., G.L. Walsh \& R.A. Yule, 1987. Insect damage to aboriginal relics at burial and rock-art sites near Carnarvon in 
Central Queensland. Journal of the Australian Entomological Society, 26: 335-345.

Recebido em: 30/05/2013

Aceito em: 16/o8/2013

\section{Como citar este artigo:}

Prestes, A.C., K.P. Tepedino, C. Kosmann \& J.R. Pujol-Luz, 2014. First Record of Rhynchotermes nasutissimus (Silvestri) (Isoptera: Syntermitinae) Associated with Rat Carrion in Brasília, Brazil. EntomoBrasilis, 7 (1): 58-61.

Acessível em: doi:10.12741/ebrasilis.v7i1.353
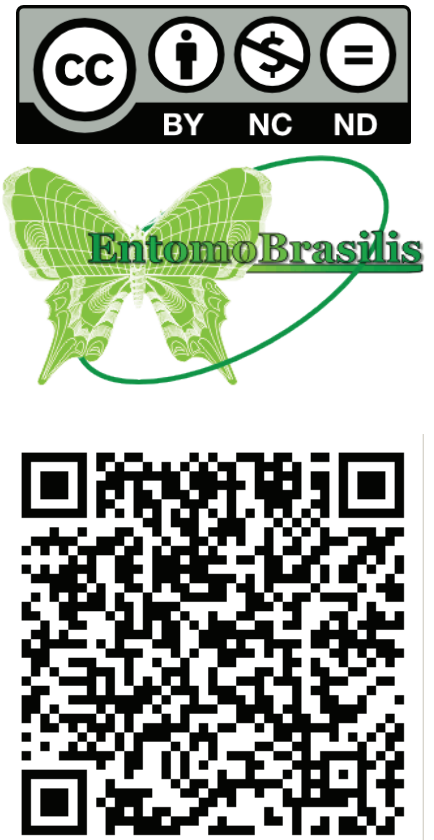